\title{
DOPING STIGMATA AS PATHOLOGICAL CLINICAL SIGNS IN THE DIAGNOSTIC FIELD OF SPORTS ANTHROPOLOGY
}

\author{
CHRIsTOPH RASCHKA
}

Institute of Sports Sciences, Julius Maximilian University, Würzburg, Germany

\begin{abstract}
An anthropometric and therefore cost-neutral screening approach as an indicator of the abuse of anabolic steroids by bodybuilders is the fat-free mass index (FFMI). Normalized to a body size of $1.80 \mathrm{~m}$, the FFMI is calculated as follows: FFMI = lean mass $($ in $\mathrm{kg}) /$ body height $(\text { in } \mathrm{m})^{2}+6.1 \times(1.8-$ body height (in $\mathrm{m})$ ). Furthermore, various physical and anthropological symptoms can be summarized as evidence of anabolic steroids or growth hormone abuse as doping signs or doping stigmata. Doping stigmata are usually identifiable doping signs in the external appearance. Typical doping signs for anabolic steroids are testicular atrophy, swollen, voluminous muscles with elusive smooth contours, exophthalmus, alopecia androgenetica, steroid acne, gynecomastia, cutis verticis gyrata, striae distensae, seborrhea, hematomas, an unproportional development of the upper body compared to the rest of the body and, in females, hirsutism, hypertrichosis, mammary atrophy and masculine growth in width, extreme reduction of subcutaneous fat percentage, lowering of the voice, clitoris hypertrophy, secondary amenorrhoea and the irreversible androgenization of a female fetus during pregnancy. Doping stigmata for growth hormone are gigantism, acromegaly, macroglossia, tooth gaps, prognathism, torus supraorbitalis, visceromegaly (cardiomyopathy, splenomegaly and hepatomegaly), hairs of wire brush consistency, edema, seborrhoea, skin thickening and hypertrichosis, cutis verticis gyrata and the reduction of the percentage of fat. Typical examples of doping signs of erythropoietin are plethora and rubeosis faciei. Doping stigmata of amphetamines are, for example, tachycardia, hypertension, decongestion, tremor, mydriasis or speed pimples.
\end{abstract}

Keywords: doping stigmata; doping signs; fat free mass index; anabolic steroids; growth hormone; erythropoietin; amphetamines 


\section{INTRODUCTION}

Body builder disorders such as inverse anorexia (synonyms: bigorexia nervosa, machismo nervosa, muscle dysmorphia) may play a role as additional doping motives, especially for recreational bodybuilders [45], primarily in the case of deficient muscle expression.

While anorectic patients often experience too much fat despite malnutrition, the inverse anorectics feel too thin and unmasculine despite Mr-Universelike body shape (Fig.1).

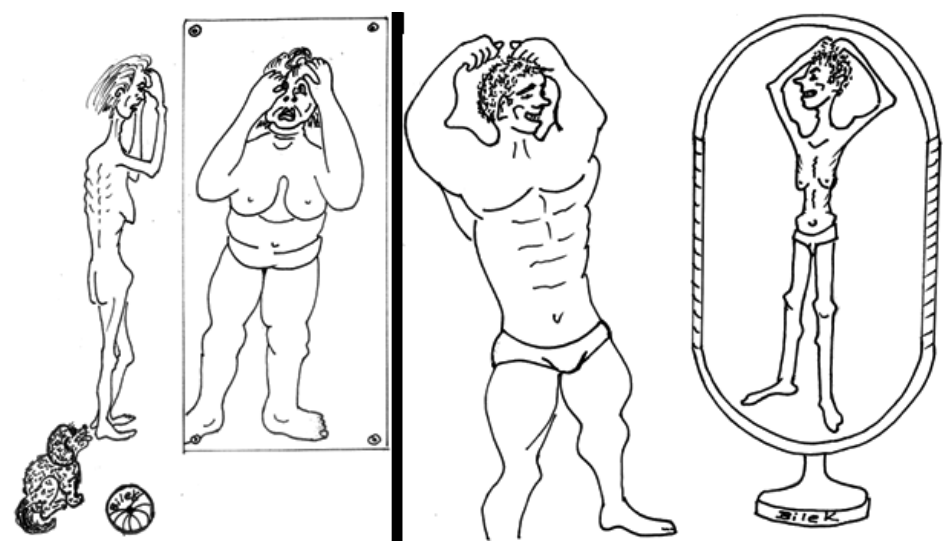

Figure 1. Cartoon: anorexia nervosa (left) vs. inverse anorexia (right)

\section{DOPING EPIDEMIOLOGY IN GERMAN FITNESS STUDIOS}

In a survey of 484 recreational athletes in 11 gyms in the area of Frankfurt/ Main, $12.9 \%$ of the men and $3.6 \%$ of the women reported taking anabolic drugs. They consumed anabolic steroids (100\%; $35 \%$ p.o., $71 \%$ parenterally), stimulants (14\%) and growth hormones (5\%). Suppliers were friends (39\%), sports mates $(28 \%)$, physicians $(28 \%)$ and coaches $(6 \%)$. The acquisition costs of an average intake for 9 weeks amounted to 175 euros. Information about doping side effects came from literature (67\%), physicians (38\%), sports mates and the so-called Black Book [72] (14\% respectively), coaches, friends and Internet (5\% respectively). $2 \%$ of the athletes with doping substances abuse were smokers, $11 \%$ had an alcoholic drink several times a week, $3 \%$ also consumed other drugs, $35 \%$ had consumed other drugs in the past. Abusers of doping substances primarily intended to increase muscle size (86\%) and strength (61\%). 


\section{A POTENTIAL SCREENING METHOD IN BODYBUILDING?}

Kouri et al. [31] introduced an anthropometric and, therefore, cost-neutral screening approach as an indicator of anabolic steroids abuse by bodybuilders: the fat-free mass index (FFMI), which could also be called the lean body mass index.

Dimensionally, it is designed analogously to the well-known body mass index (BMI), which sets the body mass in relation to the squared body height.

For the FFMI, the percentage of fat according to Jackson and Pollock [24] must first be determined using six skinfolds in $\mathrm{mm}$ (breast, thigh, suprailiacal, abdominal, subscapular and triceps skinfolds) and then, taking into account the body weight, the lean mass can be calculated.

Normalized to a body height of $1.80 \mathrm{~m}$, the FFMI is calculated as follows:

FFMI $=$ lean mass (in $\mathrm{kg}) /$ body height $(\text { in } \mathrm{m})^{2}+6.1 \times(1.8$ - body height (in $\mathrm{m})$ )

Based on an investigation on the FFMI in a collective of 157 male bodybuilders (83 users of anabolic steroids and 74 non-users), Kouri et al. [31] found that the pathological limit of the FFMI was 25.0. So-called natural bodybuilders, who oppose the use of anabolic steroids, were all below the 25.0 level, while many of the anabolic steroids users were above. Remarkably, the average value of Mr. America bodybuilding competitors of the pre-anabolic area (1930-1950) was 25.4.

\section{SIDE EFFECT PROFILES AND DOPING STIGMATA OF SELECTED DOPING SUBSTANCES}

The present publication focusses on the anabolic steroids and the growth hormone [70], which are the most important substances in the field of weight training, erythropoietin and blood doping [42], which are important for endurance sports, as well as amphetamine and cocaine from the stimulant group [29, 30].

\section{Anabolic steroids}

The effect of the anabolic steroids and androgens used in sports since the 1950s is attributed, on the one hand, to the direct increase in protein biosynthesis [70] and, on the other hand, to a more aggressive behaviour in strength training. Pharmacologically, the synthetic anabolic steroids are similar to testosterone or 19-nortestosterone. Since testosterone is rapidly metabolized and thus inactivated in the liver, incorporation of alkyl groups at position $\mathrm{C} 17$ of the 
steroid molecule (Figure 2) can modify its molecular structure with the consequence of a significantly slower enzymatic degradation in the liver. Therefore, synthetic anabolic steroids could also be applied orally. Unfortunately, these C17-alkylated androgens are not negligible in liver toxicity.

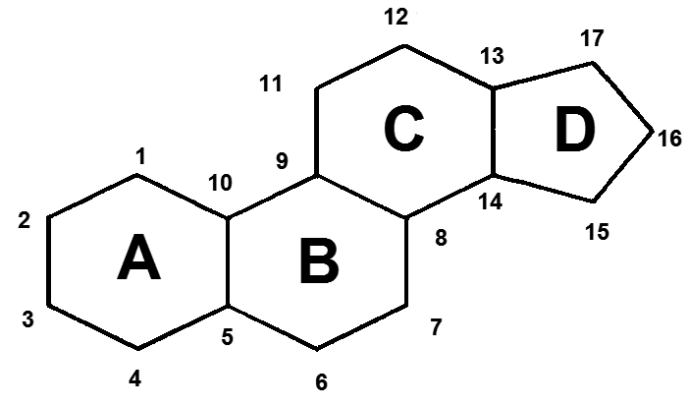

Figure 2. Basic formula of anabolic steroids

\section{Steroid doping stigmata in males}

Doping stigmata (Figure 6) are usually identifiable doping signs in the external appearance $[33,52,54,59]$.

As a result of the negative feedback inhibition, a downregulation of the hormones can take place, formed in the anterior lobe of the pituitary gland [83], which stimulates or controls the function of the male gonads, the so-called gonadotropins.

A consequence may be a large reduction in sperm in the ejaculate or the complete absence of seminal maturation cells and sperm cells in the ejaculate (azoospermia) with infertility.

In shrinking testes (= testicular atrophy), the testes are correspondingly greatly reduced.

The term "swelling muscles" [33] denotes swollen, voluminous muscles with elusive smooth contours. This is a consequence of water retention as a dreaded side effect of anabolic steroids, especially in competitive bodybuilders, which jeopardizes competitive success.

Exophthalmos (also called exophthalmus, exophthalmia, proptosis, or exorbitism) is a bulging of the eye anteriorly out of the orbit. It is a symptom of Graves' disease, which is also known as toxic diffuse goiter, an autoimmune disease that affects the thyroid. With anabolic abuse, the exophthalmos is the result of local water retention.

The causes for balding of the male type (alopecia androgenetica) are hereditary conditions, a corresponding high androgen level and age. The hair loss 
begins at the so-called receding hairline [3]. Anabolic steroids accelerate the mentioned process.

In the case of steroid acne (Fig. 3a+b), androgens stimulate sebum secretion at different ages in all age groups [3].
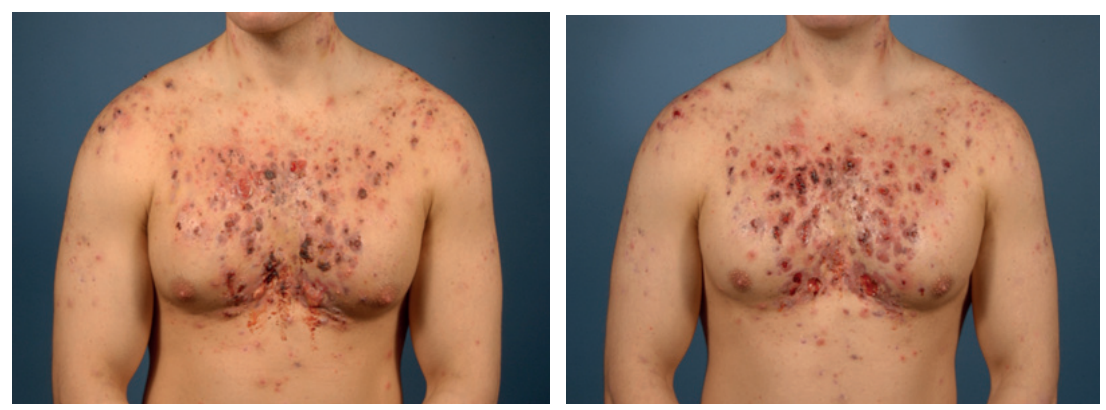

Figure $3 a+b$. Pronounced steroid acne (course) in a bodybuilder

Gynecomastia (Fig. 4) is the enlargement of the mammary gland [75], which, in principle, can occur with the supply of testosterone or anabolic steroids in every healthy male athlete. According to O'Sullivan et al. [43], its prevalence is at $20-30 \%$. This feminizing side effect of anabolic steroids is said to be caused by a compensatory increase in the production of female hormones (oestrogens) as a result of the increased intake of male hormones [33].

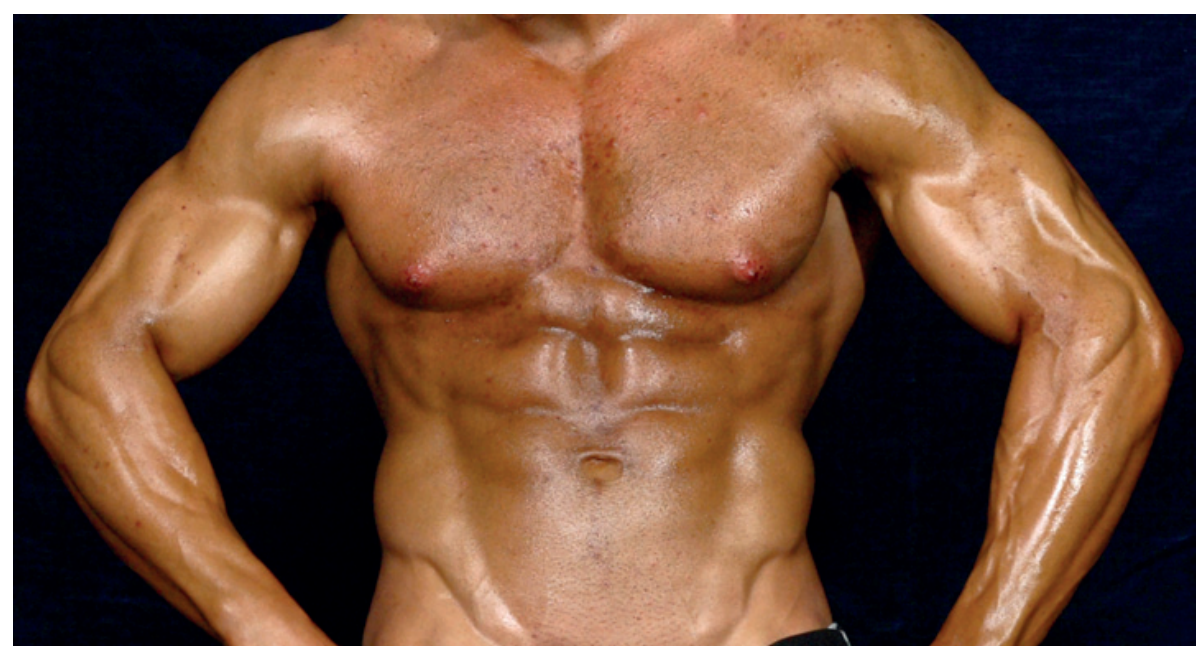

Figure 4. Initial gynecomastia in a competitive bodybuilder 
On the other hand, testosterone can also be partly converted into oestrogen in the fat and muscle tissue by means of the enzyme aromatase, so that gynecomastia can also be a direct consequence after administration of testosterone esters. Due to the possibility of the transformation of anabolic steroids into oestrogens by aromatization in the periphery, not only gynecomastia with potential chest pain is threatening in male athletes but according to some authors [58], also higher vocal tracts.

Often there is a need for surgical removal of the mammary gland (mastectomy) with areola and nipple preserved [75].

Cutis verticis gyrata, (Fig. $5 \mathrm{a}+\mathrm{b}$ ) is a fold-like thickening of the scalp which, in the clinical picture, shows a clear similarity to the folds (gyri) of the brain surface [54].

Hair growth in the furrows is usually normal but diminished on the skin folds. One risk factor is the rapid increase in muscle mass under anabolic steroids.
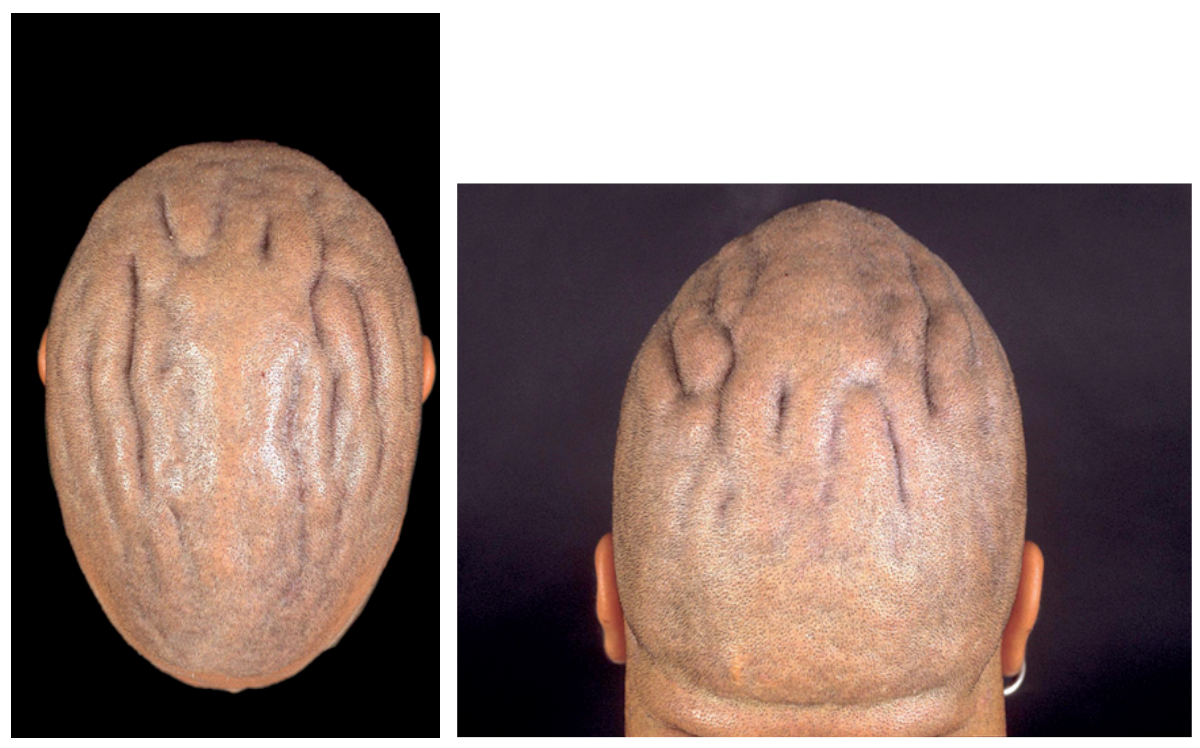

Figure $5 a+b$. Cutis verticis gyrata

Stretch marks (striae distensae) develop in the hypodermis (subcutis) as a result of excessive tissue expansion, especially in the area of the upper body and upper arm due to muscle growth that is much too rapid [3].

Seborrhea is a pathologically increased secretion of the sweat glands under anabolic steroids. 
Other signs of doping include the increased occurrence of bruising (hematomas), an disproportionate development of the upper body compared to the rest of the body, the increased risk of tendon and muscle injuries [88], accelerated maturation in adolescents and punctures of larger muscle groups as an indication of parenteral use.

\section{Doping stigmata in females}

Without medication, women in certain strength sports accomplish only $60 \%$ of male performance [48].

Sportswomen who use androgens and anabolic steroids are also threatened by the doping stigmata (Fig. 6) described in the previous section for male athletes: swelling muscles, exophthalmos, alopecia androgenetica and steroid acne, as well as increased aggressiveness (Fig.3). In addition, the following doping stigmata may occur:

Hirsutism (a male distribution pattern of terminal hair in females; [3]); hypertrichosis and mammary atrophy (loss of mammary tissue).

The most striking feature is a masculine growth in width [33].

In addition to muscle development, the extreme reduction of subcutaneous fatty tissue is particularly impressive. After discontinuation of the hormones, the hormone-induced muscles decrease again, and the percentage of fat increases in a gender-appropriate manner.

In addition, an increase in size (hypertrophy) of the thyroid cartilage and lowering of the voice can occur, analogously to the developments in pubescent boys. Clitoral enlargement (clitoris hypertrophy, clitoromegaly or megaloclitoris) can be induced by anabolic steroids.

As in the male sex, the libido in the athlete under anabolic steroids / androgens is often massively increased. The absence of menstruation under androgens / anabolic steroids is a secondary amenorrhoea.

One of the worst side effects is certainly the irreversible androgenization of the female foetus during pregnancy. The inner genitals, on the other hand, are female.

If the growth in heighth has not yet been completed, a premature epiphyseal closure can happen in both sexes [51].

\section{Liver damage caused by anabolic steroids or androgens}

Similarly to the observations under oral contraceptives, GOT, GPT and LDH can exceed the norm by 2-3 times. According to some authors [54] GOT, GPT and $\gamma$-GT reach their peak within 14 to 21 days under anabolic steroids - even 
at low dosage - and return to normal range already a few weeks after discontinuation of doping.

According to some studies, jaundice occurs up to more than $17 \%$ frequently with anabolic steroids. Gallstones can also occur frequently.

Peliosis hepatis is an uncommon vascular condition characterized by multiple, randomly distributed, blood-filled cavities throughout the liver. The size of the cavities usually ranges between a few millimetres and $3 \mathrm{~cm}$ in diameter. It is often the result of the use of C17-alkylated androgens. In isolated cases, deaths due to internal bleeding and liver failure may also be present in this disease. Many patients can also be quite symptom-free. The diagnosis is then often made only at autopsy $[68,32]$.

In addition, individual case descriptions of liver tumours such as adenomas (benign tumours of the glandular tissue or mucosa) due to anabolic steroids are documented in scientific literature, often occurring after discontinuation of the anabolic steroids. However, Sweeney and Evans [77] suspect that, under the steady influence of anabolic steroids, simple liver changes, such as liver fatty degeneration, may initially develop. Later follow-up would be Peliosis hepatis, later also liver adenomas and, in the worst case, even the development of liver cancer.

\section{Cardiovascular diseases caused by anabolic steroids and androgens}

Anabolic-androgenic steroids can [17] directly or indirectly cause cardiac arrhythmias as a consequence of direct myocardial cell damage and/or electrophysiological changes.

An unfavourable change in the lipoprotein concentration in the blood can induce premature arteriosclerosis. Arterial hypertension, increased risk of thrombosis or vasospasm are also possible [69].

The long-term use of anabolic steroids can also trigger so-called left ventricular hypertrophy (LVH) $[11,12,13,86,64,65,38,47,10,27,26,9,81$, $7,20,41,34,79,78,28]$.

\section{Other long-term consequences}

There are individual case descriptions $[39,57]$ of the development of lesser kidney damage to acute renal failure, but also on the inflammation of the filter cells in the renal corpuscles (glomerulonephritis) and even a malignant kidney tumour (Wilms tumour) under long-term effect of anabolic steroids.

There are also reports of dialysis after steroid and clenbuterol abuse over 18 months [19], of prostate cancer [63] and testicular cancer [16] as well as 
malignant diseases of the lymphatic system (non-Hodgkin's lymphoma) under anabolic steroids [80].

Dental studies also indicate an association between the use of anabolic steroids and the development of gingival hyperplasia [44].

\section{Damage to the musculoskeletal system}

From a probable total group of 1000 GDR athletes badly damaged by doping, Spitzer investigated a stratified sample of 52 persons from 24 disciplines on the Olympic level (canoe racing, rowing, athletics etc.) and interviewed them from 2004 to 2006 [73, 74]. 92\% of respondents complained of numerous musculoskeletal disorders.

A high degree of compatibility with Spitzer's publications can be found in an extensive study of 2552 former American professional football players from 2009. Horn, Gregory and Guskiewicz [23] from the University of North Carolina investigated the relationship between anabolic steroids consumption and musculoskeletal disorders. 9.1\% of respondents had used anabolic steroids during their professional career. In this study, a very significant $(\mathrm{p}<0.005)$ correlation was found between herniated discs and the use of anabolic steroids. Back pain was reported by $73.4 \%$ of anabolic steroid users compared with $54.5 \%$ of non-users. This relationship was also very significant $(\mathrm{p}<0.005)$.

\section{Growth hormone}

If the hormone were administered to children or adolescents in certain sports (basketball, football, volleyball), even if it is a horror concept, a giant growth (gigantism) could be induced.

The typical doping stigmata [52] under STH influence after completion of growth (Fig. 6) include acromegaly, a large, chubby hand, macroglossia, enlarged interdental spaces (tooth gaps), prognathism and supraorbital or supraorbital bulging (Torus supraorbitalis) [54].

Other signs are a disturbance of glucose tolerance, diabetes mellitus [67], myopathy [14], visceromegaly [54], divided into individual symptoms of cardiomyopathy, splenomegaly and hepatomegaly [69]. Characteristic of the effects of STH are also hairs of wire brush consistency, oedema and skin reactions at the site of injection [3], hirsutism, lipodystrophy and exfoliative dermatitis.

Schaffert and von Werder [67] describe the frequently complained sweat tendency, seborrhoea, skin thickening and hypertrichosis. Sinner [72] attributes nocturnal sweats and sleep disturbances to evening growth hormone injections in doping athletes. Further skin manifestations are, according to Schaffert and von Werder [67], thickened veins and nails, facial swelling, scalp thickening 
(Cutis verticis gyrata) already described in the chapter on anabolic steroids, and a carpet-like black pigmentation of the skin (acanthosis nigricans).

A desirable effect of $\mathrm{GH}$ is the reduction of the percentage of fat. However, an increase in the concentration of free fatty acids in the plasma can also be registered. Under STH influence, however, there is also an unfavourable ratio of blood lipids (dyslipidaemia) [69].

One of the consequences of cranial bone changes with the radiologically detectable thickening of the inner layer of the skull bone (tabula interna) and a significant enlargement of the frontal sinus is headache [67].

According to Kamber and Mullis [25], one symptom of intracellular water retention under STH is the so-called carpal tunnel syndrome, in addition to ankle oedema and joint pain (arthralgia). Thyroid dysfunction is the result of general visceromegaly.

The excessive cartilage growth under $\mathrm{GH}$ also leads to a nonphysiological enlargement of the joint space, so that first a cartilage nutritional disorder and then a cartilage degeneration which results in arthropathy (joint disease) [67]. Correlations between growth hormone intake and colon carcinoma, breast cancer as well as prostate cancer and leukaemia are discussed. Magnavita and coworkers [36] reported a case study on a cyclist who received growth hormone and developed Hodgkin's lymphoma (a form of malignant lymphoma). The increased development of benign skin tumours (fibroids) and colonic polyps is also typical [67].

\section{Erythropoietin and blood doping}

Erythropoietin (EPO) induces an increase of red blood cells (erythrocytes) in the blood with an increase of the erythrocyte mass and haemoglobin. As a consecutive doping sign (Fig.6), plethora and rubeosis faciei could be observed.

The hyperviscosity syndrome is a complex of symptoms that results from increased viscosity of blood.

According to Nowacki [42], the haematocrit values of certain cyclists during some races even exceeded $60 \%$. Typical symptoms of this hyperviscosity syndrome include headache, dizziness, tinnitus, hearing and vision disorders, paraesthesia, angina pectoris and syncope (fainting). According to Nowacki [42], there is an increased risk of thrombosis, hypertension, heart failure and pulmonary oedema.

Lunghetti et al. [35] reported a complicated myocardial infarction of a 50-year-old bodybuilder with consecutive cardiogenic shock after taking nandrolone and erythropoietin. Allergic reactions, haemolysis, jaundice and sepsis may happen. 


\section{Stimulants}

According to Clasing [6], stimulants are considered the "classic" doping agents which are supposed to postpone the fatigue limit directly during the competition. They may cause danger to life, above all, under the influence of additional stress factors such as heat exposure, fluid loss or trauma etc. [50, 82, 4, 8].

Koch [29] characterizes the psychophysiological effect as an escape response in acute danger. This range of effects also corresponds to some side effects such as restlessness, disinhibition, reduction in criticism, euphoria, nervousness, sleep disorders, daytime sleepiness and also turning into severe fatigue.

Even delirious symptoms with attention and consciousness disturbances or perceptual changes, delusions, visual and auditory hallucinations can occur [30].

Likewise, panic, depression, paranoia or fear of death can occur [30].

According to Forth et al. [15], amphetamine acts as an appetite inhibitor.

Acute side effects of taking amphetamines [29] are tachycardia (accelerated pulse of over 100 beats per minute), hypertension, decongestion (decongestant effect in the area of the nasal mucosa), hyperthermia, tremor, mydriasis, hypoglycaemia, bronchodilation, increased muscle tears, dehydration, rhabdomyolysis, seizures, coma, stomach bleeding, brain and heart attacks, sexual dysfunction, kidney damage, speed pimples and the serotonin syndrome (Fig.6).

\section{Cocaine}

According to Koch [30], the acute effect of cocaine is characterized by a "kick" with euphoria and happiness, subjectively increased performance, increased libido, reduction of inhibition, decrease in hunger and thirst as well as depression and anxiety. According to Koch [30], the euphoria is often followed by depressive mood.

Somatic symptoms include tachypnoea, Cheyne-Stokes respiration, tachycardia, hypertension, mydriasis, dehydration or a nasal septum damage (Fig.6).

It is also difficult to foresee potential, severe cardiac arrhythmias such as ventricular fibrillation. Logorrhoea denotes an obviously uncontrollable, hardly interruptible speech as a result of lack of self-control. As an intoxication, epileptic seizures can occur. The term hyperthermia indicates a pathological overheating of the body.

According to Koch [30], chronic side effects include brain and heart attacks, sexual dysfunction, weight loss, liver damage, severe mental dependency, paranoid hallucinatory syndromes (e.g., cocaine beetles), panic attacks or delirious 
syndromes, dysphoria, aggression, depressed-impulsive syndromes, prolonged withdrawal syndromes, embryo- and fetotoxicity.

As typical withdrawal symptoms, Koch [30] lists strong cravings, depression, anxiety, loss of drive, fatigue as well as accompanying vegetative symptoms such as sleep disturbances, sweating, vomiting and diarrhoea.

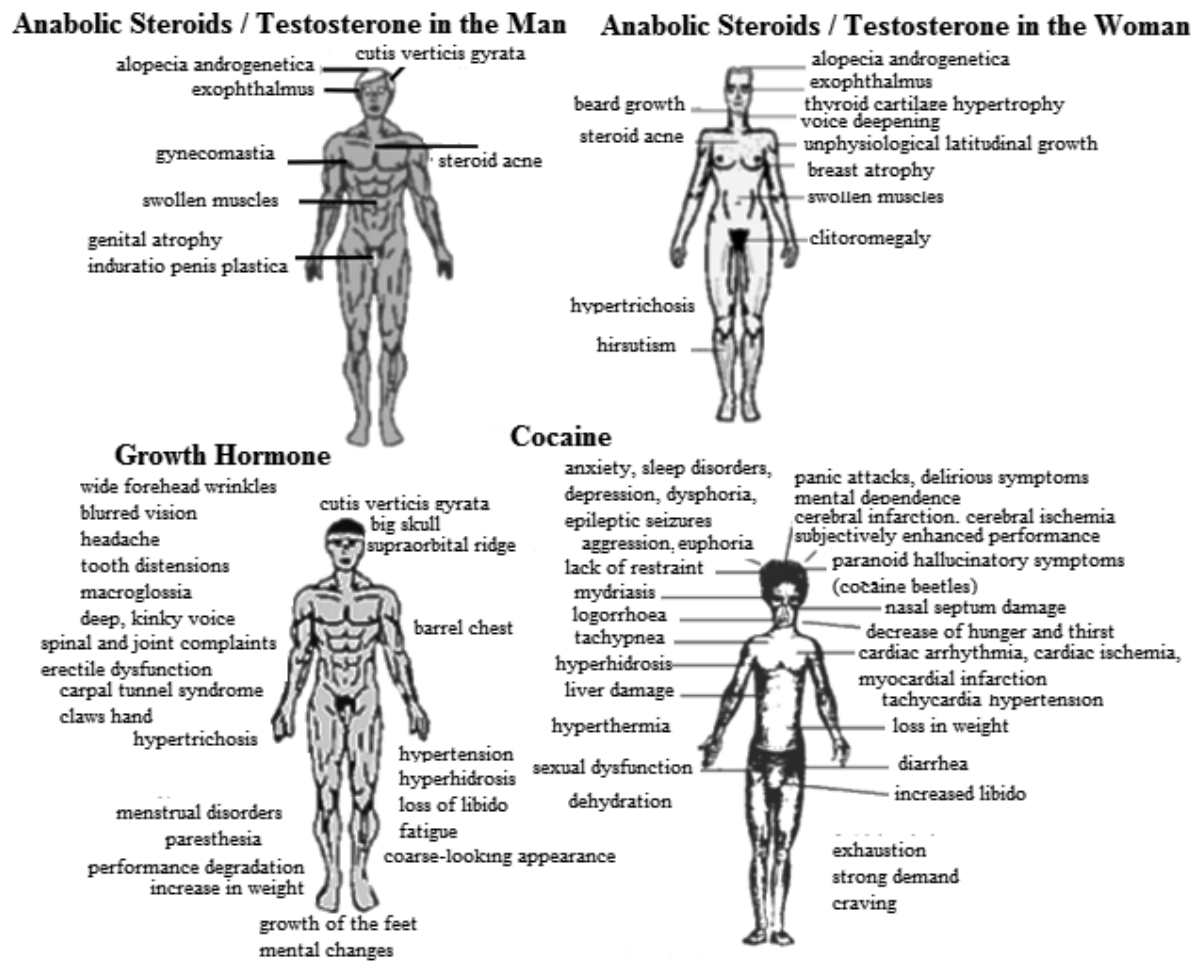

EPO / Blood Doping

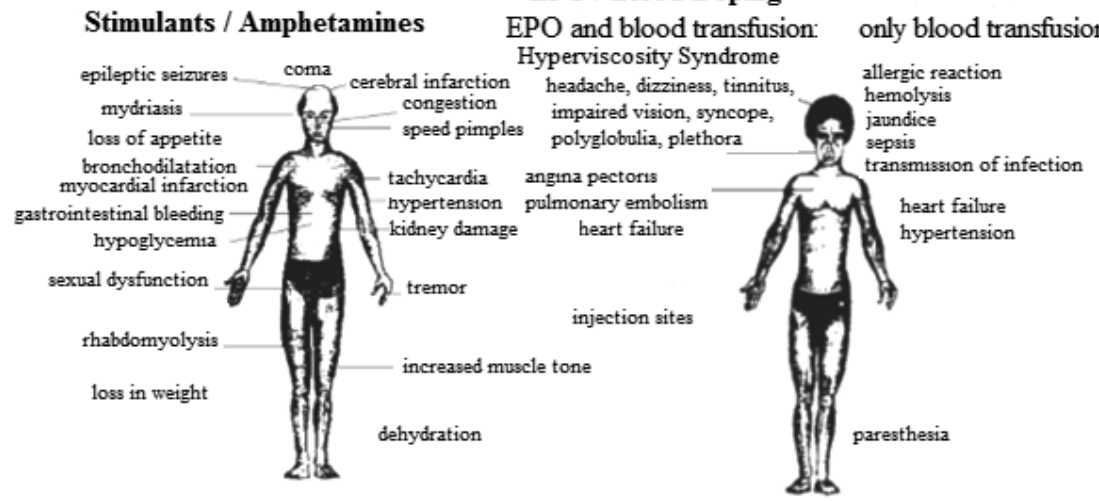

Figure 6. Synopsis of typical doping stigmata: testosterone / anabolic steroids in man and woman, growth hormone, cocaine, stimulants, EPO and blood doping 


\section{ACKNOWLEDGEMENTS}

Photos in fig. 3a+b, 4, 5a+b are taken from Raschka et al. 2010 [58]. I thank the Schattauer Verlag for permission to reproduce them.

\section{REFERENCES}

1. Aitken C., Delalande C., Stanton K. (2002). Pumping iron, risking infection? Exposure to hepatitis C, hepatitis B and HIV among anabolic-androgenic steroid injectors in Victoria, Australia. Drug and Alcohol Dependence, 65, 303-308. https://doi.org/10.1016/S0376-8716(01)00174-0

2. Augé W.K., Augé S.M. (1999). Naturalistic observation of athletic drug-use patterns and behaviour in professional-caliber bodybuilders. Substance Use \& Misuse, 34 (2), 217-249. https://doi.org/10.3109/10826089909035644

3. Axt-Gadermann M. (2010). Dermatologische Aspekte des Dopings. In C. Raschka, P.E. Nowacki, L. Zichner, R. May (Hrsg.), Doping - Wirkstoffe, fachärztliche und interdisziplinäre Aspekte (S. 103-107). Stuttgart: Schattauer.

4. Bernheim J., Cox J.N. (1960). Coup de chaleur et intoxication amphetaminique chez un sportif. Schweiz. Med. Wochenschr., 90 (1), 322-331.

5. Boos C., Wulff P., Kujath P., Bruch, H.P. (1998). Medikamentenmissbrauch beim Freizeitsportler im Fitnessbereich. Deutsches Ärzteblatt, 95, 953-957.

6. Clasing D. (Hrsg.). (2004). Doping und seine Wirkstoffe. Verbotene Arzneimittel im Sport. Balingen: Spitta Verlag GmbH \& Co. KG.

7. Climstein M. (1990). Myocardial structure and function differences between steroid using and non-steroid using elite powerlifters and endurance athletes. Dissertation. Oregon State University, USA.

8. Colman H.J., Dotzauer G. (1980). Analyse eines tödlich ausgegangenen Boxkampfes mit ungewöhnlich schweren cerebralen Schäden. Z Rechtsmed, 84, 263-278. https://doi.org/10.1007/BF02098751

9. De Piccoli B., Giada F., Benettin A., Sartori F., Piccolo E. (1991). Anabolic steroid use in body builders: an echocardiographic study of left ventricle morphology and function. Int J Sports Med, 12 (4), 408-412.

https://doi.org/10.1055/s-2007-1024703

10. Di Bello V., Giorgi D., Bianchi M., Bertini A., Caputo M.T., Valenti G., Furioso O., Alessandri L., Paterni M., Giusti C. (1999). Effects of anabolic-androgenic steroids on weight-lifters' myocardium: an ultrasonic videodensitometric study. Med Sci Sports Exerc, 31 (4), 514-521.

https://doi.org/10.1097/00005768-199904000-00004

11. Dickerman R.D., Schaller F., Prather I., McConathy W.J. (1995). Sudden cardiac death in a 20 -year-old bodybuilder using anabolic steroids. Cardiology, 86 (2), 172-173. https://doi.org/10.1159/000176867 
12. Dickerman R.D., Schaller F., Zachariah N.Y., McConathy W.J. (1997). Left ventricular size and function in elite bodybuilders using anabolic steroids. Clin J Sport Med, 7, 90-93. https://doi.org/10.1097/00042752-199704000-00003

13. Dickerman R.D., Schaller F., McConathy W.J. (1998). Left ventricular wall thickening does occur in elite power athletes with or without anabolic steroid use. Cardiology, 90 (2), 145-148. https://doi.org/10.1159/000006834

14. Fernandez M.M.F., Hosey R.G. (2009). Performance-enhancing drugs snare nonathletes, too. J Family Practice, 58, 16-23.

15. Forth W., Henschler D., Rummel W. (1990). Pharmakologie und Toxikologie. Zürich: Bibliographisches Institut \& F.A. Brockhaus AG.

16. Froehner M., Fischer R., Leike S., Hakenberg O.W., Noack B., Wirth M.P. (1999). Intratesticular leiomyosarcoma in a young man after high dose doping with Oral-Turinabol. Cancer, 86, 1571-1575. https://doi.org/10.1002/ (SICI)1097-0142(19991015)86:8\%3C1571::AID-CNCR26\%3E3.0.CO;2-C

17. Furlanello F., Serdoz L.V., Cappato, R., De Ambroggi L. (2007). Illicit drugs and cardiac arrhythmias in athletes. Eur J Cardiovasc Prev Rehabil, 4, 487-494. https://doi.org/10.1097/HJR.0b013e3280ecfe3e

18. Hartmann W. (1990). Kokain. Markt Erlbach: Raymond Martin Verlag.

19. Hartung R., Gerth J., Fünfstück R., Gröne H.-J., Stein, G. (2001). End stage renal disease in a bodybuilder: a multifactorial process or simply doping? Nephrol Dial Transplant, 16, 163-165. https://doi.org/10.1093/ndt/16.1.163

20. Hassan N.A., Salem M.F., Sayed M.A. (2009). Doping and effects of anabolic androgenic steroids on the heart: histological, ultrastructural, and echocardiographic assessment in strength athletes. Hum Exp Toxicol, 28 (5), 273-283. https://doi.org/10.1177/0960327109104821

21. Hokema F., Pietsch U.-C., Führer D., Kaisers U. (2008). Anästhesie und Bodybuilding. Anästhesiol Intensivmed Notfallmed Schmerzther, 5, 354-358. https://doi.org/10.1055/s-2008-1079108

22. Holt R.I.G., Sönksen P.H. (2008). Growth hormone, IGF-I and insulin and their abuse in sport. Brit J Pharmacology, 154, 542-556.

https://doi.org/10.1038/bjp.2008.99

23. Horn S., Gregory P., Guskiewicz K.M. (2009). Self-reported anabolic-androgenic steroids use and musculoskeletal injuries: findings from the center for the study of retired athletes health survey of retired NFL players. Am J Phys Med Rehabil, 88 (3), 192-200. https://doi.org/10.1097/PHM.0b013e318198b622

24. Jackson A.S., Pollock M.L (1978). Generalized equations for predicting body density of men. British Journal of Nutrition, 40, 497-504. https://doi.org/10.1079/BJN19780152

25. Kamber M., Mullis P.E. (2007). Doping im Jugendalter. Therapeutische Umschau 64, 83-89. https://doi.org/10.1024/0040-5930.64.2.83 
26. Karila T.A. (2003). Adverse effects of anabolic androgenic steroids on the cardiovascular, metabolic and reproductive systems of anabolic substance abusers. Dissertation. University of Helsinki, Finland.

27. Karila T.A., Karjalainen J.E., Mantysaari M.J., Viitasalo M.T., Seppala T.A. (2003). Anabolic androgenic steroids produce dose-dependent increase in left ventricular mass in power athletes, and this effect is potentiated by concomitant use of growth hormone. Int J Sports Med, 24 (5), 337-343. https://doi.org/10.1055/s-2003-40702

28. Kistler L. (2006). Todesfälle bei Anabolikamissbrauch. Todesursache, Befunde und rechtsmedizinische Aspekte. Dissertation zum Erwerb des Dr.med. an der Med.Fakultät der Ludwig-Maximilians-Universität zu München.

29. Koch H.J. (2010a). Stimulanzien und Cannabinoide. In C. Raschka, P.E. Nowacki, L. Zichner, R. May (Hrsg.), Doping - Wirkstoffe, fachärztliche und interdisziplinäre Aspekte (S. 69-79). Stuttgart: Schattauer.

30. Koch H.J. (2010b). Neurologische und psychiatrische Aspekte. In C. Raschka, P.E. Nowacki, L. Zichner, R. May (Hrsg.), Doping - Wirkstoffe, fachärztliche und interdisziplinäre Aspekte (S. 130-139). Stuttgart: Schattauer.

31. Kouri E.M., Pope H.G., Katz D.L., Oliva P. (1995). Fat-free mass index in users and non-users of anabolic-androgenic steroids. Clinical Journal of Sports Medicine, 5 (4), 223-228. https://doi.org/10.1097/00042752-199510000-00003

32. Lüderwald S., Zinka, B., Thieme, D., Eisenmenger W. (2008). Missbrauch von anabolen, androgenen Steroiden. Rechtsmedizin, 18 (3), 183-186. https://doi.org/10.1007/s00194-008-0520-0

33. Lünsch H. (2001). Anabolika-Missbrauch anders nachweisen. Balingen: Spitta Verlag $\mathrm{GmbH}$.

34. Luke J.L., Farb A., Virmani R., Sample R.H. (1990). Sudden cardiac death during exercise in a weight lifter using anabolic androgenic steroids: pathological and toxicological findings. J Forensic Sci, 35 (6), 1441-1447. https://doi.org/10.1520/JFS12981J

35. Lunghetti S., Zacà V., Maffei S., Carrera A., Gaddi R., Diciolla F., Maccherini M., Chiavarelli M., Mondillo S., Favilli R. (2009). Cardiogenic shock complicating myocardial infarction in a doped athlete. Acute Card Care, 11 (4), 250-251. https://doi.org/10.1080/17482940902842564

36. Magnavita N., Teofili L., Leone G. (1996). Hodgkin's lymphoma in a cyclist treated with growth hormone. Am J Hematol, 52, 65-66. https://doi. org/10.1002/(SICI)1096-8652(199605)52:1\%3C65::AID-AJH16\%3E3.0.CO;2-6

37. Maquirriain J. (2010). Epidemiological analysis of doping offences in the professional tennis circuit. J Occup Med Toxicol, 5, 30.

https://doi.org/10.1186/1745-6673-5-30

38. McKillop G., Todd I.C., Ballantyne D. (1986). Increased left ventricular mass in a bodybuilder using anabolic steroids. Br J Sports Med, 20, 151-152.

https://doi.org/10.1136/bjsm.20.4.151 
39. Modlinski R., Fields K.B. (2006). The effect of anabolic steroids on the gastrointestinal system, kidneys, and adrenal glands. Current Sports Med Reports, 5, 104-109. https://doi.org/10.1097/01.CSMR.0000306529.74500.f6

40. Mutschler E., Geisslinger G., Kroemer H.K., Schäfer-Korting M. (2001). Mutschler - Arzneimittelwirkungen. Lehrbuch der Pharmakologie und Toxikologie. Stuttgart: Wissenschaftliche Verlagsgesellschaft $\mathrm{mbH}$.

41. Nieminen M.S., Ramo M.P., Viitasalo M., Heikkila P., Karjalainen J., Mantysaari M., Heikkila J. (1996). Serious cardiovascular side effects of large doses of anabolic steroids in weight lifters. Eur Heart J, 17 (10), 1576-1583.

https://doi.org/10.1093/oxfordjournals.eurheartj.a014724

42. Nowacki P.E. (2010). Erythropoietin- und Blutdoping. In C. Raschka, P.E. Nowacki, L. Zichner, R. May (Hrsg.), Doping - Wirkstoffe, fachärztliche und interdisziplinäre Aspekte (S. 7-25). Stuttgart: Schattauer.

43. O’Sullivan A.J., Kennedy M.C., Casey J.H., Day R.O., Corrigan B., Wodak, A.D. (2000). Anabolic-androgenic steroids: medical assessment of present, past and potential users. Med J Aust, 173, 323-327.

https://doi.org/10.5694/j.1326-5377.2000.tb125667.x

44. Ozcelik O., Haytac M.C., Seydaoglu G. (2006). The effects of anabolic androgenic steroid abuse on gingival tissues. J Periodontol, 77, 1104-1109.

https://doi.org/10.1902/jop.2006.050389

45. Pope H.G., Phillips K.A., Olivardia R. (2001). Der Adonis-Komplex. Schönheitswahn und Körperkult bei Männern. München: DTV.

46. Parzeller M. (2010). Rechtliche Aspekte des Dopings. In C. Raschka, P.E. Nowacki, L. Zichner, R. May (Hrsg.), Doping - Wirkstoffe, fachärztliche und interdisziplinäre Aspekte (S. 31-48). Stuttgart: Schattauer.

47. Payne J.R., Kotwinski P.J., Montgomery H.E. (2004). Cardiac effects of anabolic steroids. Heart, 90, 473-475. https://doi.org/10.1136/hrt.2003.025783

48. Preiß R. (2010). Sport- und trainingswissenschaftliche Aspekte des Dopings. In C. Raschka, P.E. Nowacki, L. Zichner, R. May (Hrsg.), Doping - Wirkstoffe, fachärztliche und interdisziplinäre Aspekte (S. 159-165). Stuttgart: Schattauer.

49. Prendergast H.M., Bannen T., Erickson T.B., Honore K.R. (2003). The toxic torch of the modern Olympic games. Vet Human Toxicol, 45 (2), 97-102.

50. Prokop L. (1970). Zur Geschichte des Dopings und seiner Bekämpfung. Sportarzt Sportmedizin, 21, 125-132.

51. Radike K., Hebestreit H. (2010). Pädiatrische Aspekte des Dopings. In C. Raschka, P.E. Nowacki, L. Zichner, R. May (Hrsg.), Doping - Wirkstoffe, fachärztliche und interdisziplinäre Aspekte (S. 99-103). Stuttgart: Schattauer.

52. Raschka C. (2006). Sportanthropologie. Leitfaden der modernen, vergleichenden Sportanthropologie, Sportanthropometrie und trainingsrelevanten Konstitutionsbiologie. Köln: Sportverlag Strauß. 
53. Raschka C. (2008). Tödliche Dopingfälle im Sport. Ein historischer Überblick. Rechtsmedizin, 18, 173-176. https://doi.org/10.1007/s00194-008-0524-9

54. Raschka C. (2010). Allgemeinmedizinische und internistische Aspekte des Dopings. In C. Raschka, P.E. Nowacki, L. Zichner, R. May (Hrsg.), Doping Wirkstoffe, fachärztliche und interdisziplinäre Aspekte (S. 107-121). Stuttgart: Schattauer.

55. Raschka C., Chmiel, C., Preiß R., Boos C. (2013a). Doping bei Freizeitsportlern. Eine Untersuchung in 11 Fitnessstudios im Raum Frankfurt am Main. MMWFortschritte der Medizin Originalien, 155 (II), 41-43. https://doi.org/10.1007/s15006-013-1052-4

56. Raschka C., Chmiel C., Preiß R., Boos C. (2013c). Wie verbreitet ist Doping bei Freizeitsportlern? Umfrage in Fitnessstudios. MMW-Fortschritte der Medizin, 155 (14), 57. https://doi.org/10.1007/s15006-013-2043-1

57. Raschka C., Löhr D., Fassbinder W. (1996). Akute bedrohliche Nebenwirkungen bei wettkampforientierter Selbstmedikation eines Bodybuilders. Deutsche Zeitschrift für Sportmedizin, 47, 539-542.

58. Raschka C., Nowacki P.E., Zichner L., May R. (2010). Doping - Wirkstoffe, fachärztliche und interdisziplinäre Aspekte. Stuttgart: Schattauer.

59. Raschka C., Zedler B., Parzeller M. (2008). Doping im Sport - Teil 1: WADAund NADA-Code. Verbotsliste und medizinische Aspekte. StoffR, 5, 102-118.

60. Raschka C., Ziegler R., Grebe W., Vennemann N., Schmidt-Saloff S., Tusk, I. (2013b). Doping 2012 - aktuelle Befragung hessischer SportmedizinerInnen zur Erfahrung mit Doping. Prävention und Rehabilitation, 25 (1), 25-29. https://doi.org/10.5414/PRX00441

61. Rickert V.I., Pawlak-Morello C., Sheppard V., Jay M.S. (1992). Human growth hormone: a new substance of abuse among adolescents? Clin Pediatr, 12, 723726. https://doi.org/10.1177/000992289203101206

62. Rich J.D., Dickinson B.P., Feller A., Pugatch D., Mylonakis E. (1999). The infectious complications of anabolic-androgenic steroid injection. Int J Sports Med, 20, 563-566. https://doi.org/10.1055/s-1999-8841

63. Roberts J.T., Essenhigh D.M. (1986). Adenocarcinoma of prostate in 40-yearold bodybuilder. Lancet, 2 (8509), 742.

https://doi.org/10.1016/S0140-6736(86)90251-5

64. Sachtleben T.R., Berg K.E., Elias B.A., Cheatham J.P., Felix G.L., Hofschire P.J. (1993). The effects of anabolic steroids on myocardial structure and cardiovascular fitness. Med Sci Sports Exerc, 25, 1240-1245.

https://doi.org/10.1249/00005768-199311000-00006

65. Sader M.A., Griffiths K.A., McCredie R.J., Handelsman D.J., Celermajer D.S. (2001). Androgenic anabolic steroids and arterial structure and function in male bodybuilders. J Am Coll Cardiol, 37, 224-230.

https://doi.org/10.1016/S0735-1097(00)01083-4 
66. Scarpino V., Arrigo A., Benzi G., Garattini S., La Vecchia C., Bernardi L.R., Silvestrini G., Tuccimei G. (1990). Evaluation of prevalence of "doping" among Italian athletes. Lancet, 336 (8722), 1048-1050. https://doi.org/10.1016/0140-6736(90)92502-9

67. Schaffert S., von Werder K. (2001). Akromegalie. Vom Symptom zu Diagnose und Therapie. Berlin, Heidelberg, New York: Springer-Verlag.

68. Schmidt P., Kettner M., Zedler B., Parzeller M. (2010). Rechtsmedizinische Aspekte des Dopings. In C. Raschka, P.E. Nowacki, L., Zichner, R. May (Hrsg.), Doping - Wirkstoffe, fachärztliche und interdisziplinäre Aspekte (S. 150-158). Stuttgart: Schattauer.

69. Schöneberger A. (2010). Kardiologische Aspekte des Dopings. In C. Raschka, P.E. Nowacki, L. Zichner, R. May (Hrsg.), Doping - Wirkstoffe, fachärztliche und interdisziplinäre Aspekte (S. 121-130). Stuttgart: Schattauer.

70. Schulze J. (2010). Anabole Wirkstoffe, Hormone und verwandte Stoffe, Beta2-Agonisten und Maskierungsmittel. In C. Raschka, P.E. Nowacki, L. Zichner, R. May (Hrsg.), Doping - Wirkstoffe, fachärztliche und interdisziplinäre Aspekte (S. 56-69). Stuttgart: Schattauer.

71. Siegmund-Schultze N. (2013). Trainieren mit allen Mitteln - leistungsbeeinflussende Substanzen im Breiten- und Freizeitsport. Deutsches Ärzteblatt, 110 (29-30) A1422-1425.

72. Sinner D. (2010). Anabole Steroide. Das Schwarze Buch. Gronau: BMS Verlag.

73. Spitzer G. (2004). Doping in der DDR - ein historischer Überblick zu einer konspirativen Praxis. Band 3. 3. Auflage. Köln: Sport und Buch Strauß.

74. Spitzer G. (2007). Wunden und Verwundungen. Sportler als Opfer des DDRDopingsystems. Köln: Sportverlag Strauß.

75. Stitz B. (2010). Gynäkologische und andrologische Aspekte des Dopings. In C. Raschka, P.E. Nowacki, L. Zichner, R. May (Hrsg.), Doping - Wirkstoffe, fachärztliche und interdisziplinäre Aspekte (S. 143-150). Stuttgart: Schattauer.

76. Strano Rossi S., Botrè F. (2011). Prevalence of illicit drug use among the Italian athlete population with special attention on drugs of abuse: a 10-year review. J Sports Sci, 29 (5), 471-476. https://doi.org/10.1080/02640414.2010.543915

77. Sweeney E.C., Evans D.J. (1976). Hepatic lesions in patients treated with synthetic anabolic steroids. J Clin Pathol, 29, 626-633.

https://doi.org/10.1136/jcp.29.7.626

78. Tagarakis C.V.M. (2012). Androgenic anabolic steroids, exercise and the heart. Köln: Sportverlag Strauß.

79. Tagarakis C.V., Bloch W., Hartmann G., Hollmann W., Addicks K. (2000). Anabolic Steroids impair the exercise-induced growth of the cardiac capillary bed. Int J Sports Med, 21, 412-418. https://doi.org/10.1055/s-2000-3835

80. Tentori L., Graziani G. (2007). Doping with growth hormone/IGF-1, anabolic steroids or erythropoietin: is there a cancer risk? Pharmacological Research, 55, 359-369. https://doi.org/10.1016/j.phrs.2007.01.020 
81. Urhausen A., Holpes R., Kindermann W. (1989). One- and two-dimensional echocardiography in bodybuilders using anabolic steroids. Eur J Appl Physiol, 58 (6), 633-640. https://doi.org/10.1007/BF00418510

82. Venerando A. (1963). Doping: Pathology and ways to control it. Medicina dello Sport, 3, 945.

83. Vorona E., Nieschlag E. (2012). Sequelae of doping with anabolic steroids. In: E. Nieschlag, H.M. Behre, S. Nieschlag (Eds.), Testosterone: Action, Deficiency, Substitution (pp. 535-546). Cambridge: University Press.

84. Wadler G.I., Hainline B. (1989). Drugs and the athlete. Philadelphia: F.A. Davis Company.

85. Wanjek B., Rosendahl J., Strauss B., Gabriel H.H. (2007). Doping, drugs and drug abuse among adolescents in the State of Thuringia (Germany): prevalence, knowledge and attitudes. Int J Sports Med, 28 (4), 346-353. https://doi.org/10.1055/s-2006-924353

86. Yeater R., Reed C., Ullrich I., Morise A., Borsch M. (1996). Resistance trained athletes using or not using anabolic steroids compared to runners: effects on cardiorespiratory variables, body composition, and plasma lipids. Br J Sports Med, 30, 11-14. https://doi.org/10.1136/bjsm.30.1.11

87. Zaugg M., Jamali N.Z., Lucchinetti E., Xu W., Alam M., Shafiq S.A., Siddiqui M.A. (2001). Anabolic-androgenic steroids induce apoptotic cell death in adult rat ventricular myocytes. J Cell Physiol, 187, 90-95. https://doi. org/10.1002/1097-4652(2001)9999:9999\%3C00::AID-JCP1057\%3E3.0.CO;2-Y

88. Zichner L. (2010). Orthopädische Aspekte des Dopings. In C. Raschka, P.E. Nowacki, L. Zichner, R. May (Hrsg.), Doping - Wirkstoffe, fachärztliche und interdisziplinäre Aspekte (S. 139-142). Stuttgart: Schattauer.

\section{Address for correspondence:}

Prof. Dr.med. Dr.rer.nat. Dr.Sportwiss. Christoph Raschka

Institute of Sports Sciences, Julius Maximilian University, Germany

Judenbühlweg 11

D-97082 Würzburg

E-mail: christoph.raschka@uni-wuerzburg.de 